\title{
Bilateral internal ophthalmoplegia in a patient with sarcoidosis
}

\author{
PAUL HENKIND AND MARVIN B. GOTTLIEB \\ From the Department of Ophthalmology, Albert Einstein College of Medicine/Montefiore Hospital \\ and Medical Center, New York
}

Ocular signs are common in systemic sarcoidosis. Upwards of 50 per cent. of affected patients develop a granulomatous anterior uveitis, and fundus lesions are frequently observed. Ocular findings due to central nervous system involvement are less frequent, but can be the initial complaint. The subject of central nervous system involvement in sarcoidosis has been reviewed by Colover (1948) and Walsh and Hoyt (1969a).

In this paper, we report a patient whose initial ocular manifestation of sarcoidosis was an internal ophthalmoplegia. Her systemic illness went undiagnosed for many months until she developed a severe bilateral granulomatous uveitis and secondary glaucoma. The literature dealing with internal ophthalmoplegia in sarcoidosis is reviewed.

\section{Case report}

An obese 40-year-old Negro nurse was admitted to the hospital in October, 1970, because of severe bilateral decrease in visual acuity. She had been well until February, 1970, when shé developed a "flu-like" syndrome which was followed by persistent fever, malaise, anorexia, lower extremity weakness, myalgia, and paresthesias. She also developed a rash on the legs. In March, 1970, she was noted to have pyuria for which she was given Negram $(\mathbb{B})$ and Furadantin $\left({ }^{\mathbb{R}}\right)$, and she also complained of nervousness for which she was given chlorpromazine; 2 weeks later, she noted some blurred vision in the left eye and the chlorpromazine was discontinued, but the vision did not improve. She was next seen on May 7,1970 , in the psychiatric emergency room, complaining of depression, progressive weakness, and recurring spiking fevers to $103^{\circ} \mathrm{F}$. She was seen by the neurology service to rule out organic disease.

\section{Examination}

She had difficulty in walking, a temperature of $102^{\circ} \mathrm{F}$., a $5 \mathrm{~mm}$. diameter left pupil, with sluggish reaction, and a $2 \mathrm{~mm}$. diameter reactive right pupil. Ocular motility and fundus findings were described as normal. A spinal tap revealed an opening pressure of $170 \mathrm{~mm}$. Hg., $94 \mathrm{mg}$. per cent. protein and 48 per cent. glucose.

The diagnosis of Adie's pupil was considered likely and a full medical examination planned.

She was re-examined on May 26 because of increasing weakness and bilateral blurring of vision of 2 weeks' duration. At this time, the right pupil measured $5 \mathrm{~mm}$. and the left $4 \mathrm{~mm}$. in diameter. Both had sluggish reactions to light and accommodation. The patient was felt to have "hyperventilation syndrome" and anxiety.

\section{Ophthalmological examination}

She was first examined in the Eye Clinic on June 5, r970. The visual acuity was 20/50 in the right eye, $20 / 20$ with $+\mathrm{I} \cdot 5 \mathrm{D}$ sph.; and $20 / 40$ in the left eye, 20/20 with $+0.5 \mathrm{D}$. sph. There was slight ptosis, more marked on the right side. Applanation tensions were $14 \mathrm{~mm}$. $\mathrm{Hg}$ 
in the right eye and $16 \mathrm{~mm} . \mathrm{Hg}$ in the left. Slit-lamp examination revealed normal anterior segments and gonioscopy revealed wide-open angles without synechiae. Both pupils were widely dilated and failed to react either to light or accommodation. There was no measurable accommodation in either eye. The fundi appeared to be within normal limits.

On June $\mathrm{i} 7$, the patient returned to the clinic for pharmacological testing of the pupils which were still dilated and unresponsive; accommodation was still absent. The pupils measured $7 \mathrm{~mm}$. right and $6 \mathrm{~mm}$. left. Methacholine 2.5 per cent. and phenylephrine ro per cent. had no effect on the pupils. Pilocarpine 4 per cent. caused a moderate constriction to $4-5 \mathrm{~mm}$. in each eye. The patient denied using mydriatic or cycloplegic agents.

In July, I970, the patient noted bilateral preauricular swellings which lasted about one week and spontaneously subsided. She next visited the clinic on October 10, 1970, and gave a history of 5 days of poor vision. The best corrected visual acuity was hand movements in each eye. The applanation tension was $40 \mathrm{~mm}$. $\mathrm{Hg}$ in each eye. There were bilateral microcystic corneal oedema and mutton fat keratic precipitates; several small nodules on the pupillary margin of the right iris; moderate cells and flare; bilaterally fixed and dilated pupils without evident posterior synechiae. Fundoscopy was impossible initially, but after 2 days of topical steroids and oral Diamox, fluffs of exudate were noted in both vitreous cavities inferiorly. The retinal veins appeared to be sheathed, and yellow-white fundus lesions were evident.

\section{Systemic examination}

There was pretibial scaling and hyperpigmentation. There was no systemic lymphadenopathy, salivary gland enlargement, or hepatosplenomegaly. Neurological examination revealed a peripheral neuropathy, proximal muscle weakness, and a positive Romberg's sign. Sarcoid was considered the most likely diagnosis.

\section{Laboratory studies}

The following were within normal limits: complete blood count, urine analysis, calcium, phosphorus, albumin, globulin, serology, toxoplasmosis dye titre, and histoplasmin and tuberculin skin tests.

Abnormal findings included an erythrocyte sedimentation rate of $4 \mathrm{I} \mathrm{mm}$. Ist hr, serum uric acid $8 \cdot 2 \mathrm{mg}$. per cent., and a spinal tap with an opening pressure of $\mathrm{I} 4 \mathrm{O} \mathrm{mm}$. $\mathrm{Hg}$, protein $66 \mathrm{mg}$. per cent., glucose $60 \mathrm{mg}$. per cent., and a chloride $127 \mathrm{mEq} / \mathrm{L}$.

Chest $x$-rays revealed bilateral hilar adenopathy, read by several physicians as consistent with the diagnosis of sarcoidosis. Hand and skull $x /$ rays were unremarkable.

Electromyography of the anterior tibialis and external digital muscles indicated a polyneuropathic pattern, but no myopathy.

The anterior tibialis muscle was biopsied and histopathological examination revealed striated muscle with foci of non-caseating granulomatous inflammation consistent with the diagnosis of sarcoidosis.

Acid fast and periodic acid-Schiff stains were negative for tubercle bacilli and fungi. Pulmonary function studies revealed a restrictive pattern with decreased diffusion capacity. Both the pulmonary and neurology departments believed that the overall picture was consistent with the diagnosis of sarcoidosis.

\section{Treatment}

Systemic steroids were given and the patient's general health improved. The uveitis and secondary glaucoma resolved, but the internal ophthalmoplegia persisted. In May, 1971, the anterior uveitis recurred, but the visual acuity remained $20 / 20$ in each eye. The pupils were slightly irregular, $4 \mathrm{~mm}$. in diameter, and reacted slightly to accommodation, but not to light. In May, 1972, the uncorrected visual acuity was $20 / 20$ in each eye, both pupils were $4 \mathrm{~mm}$. in diameter, and there was a granulomatous uveitis in the right eye. 


\section{Discussion}

In retrospect, the patient's initial symptoms were consistent with the diagnosis of systemic sarcoidosis. It was not, however, until she developed severe anterior uveitis that a definitive study was made and the diagnosis confirmed by biopsy and positive pulmonary function studies. The raised protein content of the cerebrospinal fluid pointed to possible central nervous system involvement.

Perhaps the most distinctive and puzzling feature of the present case was the bilateral internal ophthalmoplegia. This apparently developed initially as a left internal opthalmoplegia, but within 2 months became bilateral. The pupillary paralysis has persisted for at least 2 years. It could not be attributed to previous uveitis nor to self-medication with mydriatics. Definitive reference sources (Walsh and Hoyt, I $969 b$; Duke-Elder and Scott, I97 I) make little mention of internal ophthalmoplegia as a sign of sarcoidosis, but a review of the literature has revealed a number of cases of pupillary abnormalities in patients with sarcoidosis (Table, opposite). Among the cases several are of special note:

Lewis (I94I) reported a 53-year-old female with inactive pupils-there being no response to light or accommodation. The pupils were described as "Adie's pupils", but no pharmacological studies were conducted. Höök (1954) mentioned one case of a 58-year-old female with "Argyll Robertson pupils", and stressed that pupillary abnormalities were rare in sarcoidosis. Case I of Matthews (1959), a 35-year-old female presented initially with an unresponsive, dilated right pupil and later with bilateral "Argyll Robertson" pupils. Wells (1967) reported a 25-year-old man who presented with inactive pupils, ptosis, absent knee jerks, and Rombergism. Donin (1970) described a 28-yearold female who presented initially with a right-sided Adie's pupil and bilateral papilloedema. In the two last instances, and in several of the other cases noted in the Table, the patients had previous anterior uveitis, which may have caused the pupillary abnormalities. Only the patients of Dopter (1904), Tait (1934), Donin (1970), and the present case were noted to have cycloplegia.

The nature of the internal ophthalmoplegia in the present case was investigated pharmacologically. Pilocarpine induced a moderate temporary constriction, thereby establishing the integrity of the iris sphincter. Cholinergic hypersensitivity of the sphincter was tested with a weak solution of methacholine, and the lack of response indicated absence of a post-ganglionic lesion. One must, therefore, postulate a lesion of the efferent pupillomotor and accomodative pathway central to the ciliary ganglion. The presence of bilateral involvement suggests a circumscribed rostral midbrain lesion, involving both the pupillary and accommodative centres. Jampel and Mindel (1967) have demonstrated, in monkeys, contiguous cell masses subserving pupillary constriction and accommodation which overlap in an intermediate zone. Presumably, man also has such an overlapping area in the midbrain. On the other hand, the fact that the left internal ophthalmoplegia occurred weeks to months before the right-sided involvement may be in favour of two separate central nervous system lesions. Placement of such lesions is purely speculative, but they were certainly distal to the ciliary ganglia.

Other causes of fixed dilated pupils were ruled out. Careful questioning and observation precluded self-induced internal ophthalmoplegia by atropinization. Pineal tumours may produce fixed and unreactive pupils, but generally have an associated supranuclear paralysis of conjugate upward gaze. According to Walsh and Hoyt (I969b), "Bilateral complete paralysis and dilation of the pupils in disease of the midbrain rarely occurs alone". Vascular disease and plaques from demyelinating disease affecting the rostral portion of the oculomotor nuclear complex usually produce associated signs, such as nuclear ophthalmoplegia, paralysis of upward gaze, loss of convergence, exotropia, and other defects of ocular movement. A wide variety of infectious diseases may cause an 
Table Internal ophthalmoplegia in systemic sarcoidosis

\begin{tabular}{|c|c|c|c|c|c|c|}
\hline Author & Date & $\begin{array}{l}\text { Age } \\
(y r s)\end{array}$ & Sex & Race & $\begin{array}{l}\text { Manifestations of internal ophthalmo- } \\
\text { plegia }\end{array}$ & Other data \\
\hline Dopter & I 904 & 31 & $\mathbf{M}$ & C & $\begin{array}{l}\text { Mydriasis and paresis of accommo- } \\
\text { dation left eye }\end{array}$ & $\begin{array}{l}\text { Left facial paralysis } \\
\text { (central) }\end{array}$ \\
\hline Mackay & I 92 I & $?$ & $\mathbf{F}$ & G & $\begin{array}{l}\text { Pupils dilated and immobile to } \\
\text { light but contracted to convergence }\end{array}$ & $\begin{array}{l}\text { Previous "deep punctate } \\
\text { keratitis" }\end{array}$ \\
\hline $\begin{array}{l}\text { Critchley } \\
\text { and } \\
\text { Phillips }\end{array}$ & 1924 & $5^{1}$ & $\mathrm{~F}$ & G & $\begin{array}{l}\text { Pupils small and equal, circular in } \\
\text { shape, and reacted sluggishly to } \\
\text { light but not to accommodation }\end{array}$ & $\begin{array}{l}\text { Ptosis present, especially } \\
\text { right-sided } \\
\text { Probable old anterior } \\
\text { uveitis } \\
\text { Negative serology }\end{array}$ \\
\hline Tait & I 934 & 27 & $\mathbf{M}$ & $\mathrm{G}$ & $\begin{array}{l}\text { Pupils semi-dilated and reacted } \\
\text { briskly to light, and sluggishly to } \\
\text { accommodation } \\
\text { "Cycloplegia of the left eye" }\end{array}$ & $\begin{array}{l}\text { Bilateral anterior uveitis } \\
\text { Negative Wassermann, } \\
\text { reaction }\end{array}$ \\
\hline Lewis & I 94 I & 53 & $\mathbf{F}$ & G & $\begin{array}{l}\text { Bilaterally inactive pupils; no res- } \\
\text { ponse to light or accommodation }\end{array}$ & $\begin{array}{l}\text { Absent ankle and R. knee- } \\
\text { jerk } \\
\text { Adie's syndrome } \\
\text { R. disc? mild oedema } \\
\text { L. disc? optic atrophy } \\
\text { Negative serology }\end{array}$ \\
\hline Krabbe & I 945 & I 3 & $\mathbf{F}$ & C & $\begin{array}{l}\text { Pupils dilated with loss of pupillary } \\
\text { reflex to light }\end{array}$ & $\begin{array}{l}\text { Uveitis } \\
\text { Optic neuritis, } \\
\text { multiple neurological } \\
\text { symptoms }\end{array}$ \\
\hline Pennell & I95I & $4^{8}$ & $\mathbf{M}$ & $\mathrm{N}$ & $\begin{array}{l}\text { Irregular, unequal pupils almost } \\
\text { fixed to light } \\
\text { Accommodation not mentioned }\end{array}$ & $\begin{array}{l}\text { Left } 6 \text { th nerve palsy } \\
\text { Negative serology }\end{array}$ \\
\hline Höök & I954 & 59 & $\mathbf{F}$ & C & $\begin{array}{l}\text { Pupils irregular and unequal, fixed } \\
\text { to light and sluggish to accommo- } \\
\text { dation-convergence }\end{array}$ & $\begin{array}{l}\text { Patient had TBC } \\
\text { Negative serology }\end{array}$ \\
\hline Mattheus & $\begin{array}{l}1959 \\
1965\end{array}$ & 35 & $\mathbf{F}$ & G & $\begin{array}{l}\text { Initially, R. pupil dilated and non- } \\
\text { reactive to light or convergence } \\
\text { Later, pupils irregular, unequal in } \\
\text { size and non-reactive to light, but } \\
\text { responsive to convergence (Argyll } \\
\text { Robertson pupils) }\end{array}$ & Normal serology \\
\hline Wells & I 967 & 25 & $\mathbf{M}$ & C & Inactive pupils & $\begin{array}{l}\text { Ptosis, previous acute } \\
\text { iritis, inactive knee-jerks, } \\
\text { Rombergism } \\
\text { Negative serology }\end{array}$ \\
\hline Donin & I 970 & 28 & $\mathrm{~F}$ & $\mathrm{C}$ & $\begin{array}{l}\text { Right pupil dilated, barely reactive } \\
\text { to light and convergence, lacked } \\
\text { accommodation }\end{array}$ & $\begin{array}{l}\text { Papilloedema both eyes } \\
\text { Right anterior uveitis } \\
\text { Later bilateral uveitis }\end{array}$ \\
\hline $\begin{array}{l}\text { Present } \\
\text { case }\end{array}$ & & 40 & $\mathbf{F}$ & $\mathrm{N}$ & $\begin{array}{l}\text { Dilated pupils fixed to light and } \\
\text { accommodation }\end{array}$ & See text \\
\hline
\end{tabular}

isolated internal ophthalmoplegia, and these include: herpes zoster, chickenpox, measles, diphtheria, syphilis, scarlet fever, pertussis, smallpox, influenza, and possibly infectious hepatitis. In these instances the ophthalmoplegia is usually transient. There was no 
evidence that the patient had a systemic disease other than sarcoid, and her "flu-like" symptoms are readily explained by this condition.

We suggest that a focal granuloma of sarcoid lodged in the rostral midbrain caused the patient's bilateral internal ophthalmoplegia. Sarcoidosis should be considered in the differential diagnosis of internal ophthalmoplegia.

\section{Summary}

A 40-year-old black female with sarcoidosis had involvement of the eyes, muscles, nervous system, and lungs. Peculiar to this case was the unusual findings of a bilateral internal ophthalmoplegia as the presenting ocular sign. The possible location of the lesion causing the internal ophthalmoplegia was thought to be in the rostral midbrain. A review of the literature confirms the fact that pupillary signs may occur in central nervous system sarcoidosis.

\section{References}

COLOVER, J. (1948) Brain, 7r, 45 I

CRITCHLEY, M., and PHILLIPS, P. (1924) Lancet, 2, 906

DONIN, J. F. (1970) "Neuro-ophthalmology Symposium", ed. J. L. Smith, vol. 5, p. 81. Huffman, Hallandale, Fla.

DOPTER, м. (1904) Gaz. Hôp. Paris, 77, 857

DUKE-ELDER, s., and SCOTT, G. I. ( I97 I ) "System of Ophthalmology", vol. I 2, "Neuro-ophthalmology".

Kimpton, London

нӧӧк, о. (1954) A.M.A. Arch. Neurol. Psychiat., 71, 554

JAMPEL, R. S., and MiNDEL. J. (1967) Invest. Ophthal., 6, 40

KRABBE, к. н. (1945) Nord. Med., 25, 708

LEWIS, G. E. (I94I) Brit. med. F., 1, $55^{2}$

MACKAy, G. (1921) Trans. ophthal. Soc. U.K., 41, 209

mattheWs, W. B. (1959) Brit. med. F., I, 267

- (1965) F. Neurol. Neurosurg. Psychiat., 28, 23

Pennell, w. H. (I95I) A.M.A. Arch. Neurol. Psychiat., 66, 728

TAIT, C. B. v. (1934) Lancet, 2, 748

WALSH, F. B., and HOYT, w. F. (I969a) "Clinical Neuro-ophthalmology," 3rd ed., vol. 2, p. 1452.

Williams and Wilkins, Baltimore

(1969b) Idem, vol. I, p. 494

wells, c. E. c. (1967) Proc. roy. Soc. Med., 6o, I 172 